\title{
幼児期における開眼片足立ち測定の妥当性の検討
}

\section{The validity of measuring pre-school children's ability to stand on one leg with eyes open}

\begin{abstract}
久保 温子 ${ }^{1)}$, 村田 伸 ${ }^{2}$, 平尾 文 ${ }^{11}$, 小㴊可奈子 ${ }^{3)}$
Atsuko Kubo ${ }^{1)}$, Shin Murata ${ }^{2)}$, Aya HiraO ${ }^{1)}$, Kanako Obuchi3)

要旨：【目的】本研究の目的は、幼児に扔ける開眼片足立ちと幼児運動能力調查項目值と の関連性から、幼児期の開眼片足立ち測定の妥当性を検討した。【対象】健常年中、年長 児173名とし、平均月齢は66.9 9 . 8 8月であった。【方法】開眼片足立ち時間を測定した 後、文部科学省の示した幼児運動能力調査より、 $25 \mathrm{~m}$ 走、立ち幅跳び、ボール投げ、両足 跳び越し、体支持時間を評価した。開眼片足立ち時間と各運動能力測定値との関連をピア ソンの相関係数から検討した。【結果】開眼片足立ち時間は、 $25 \mathrm{~m}$ 走、立ち幅跳び、両足 跳び越し、体支持時間で有意な相関が認められた。【結語】幼児の開眼片足立ちは多くの 運動機能を反映する評価であり、幼児期に㧍ける開眼片足立ち測定の妥当性が示唆された。

キーワード : 幼児・開眼片足立ち・幼児運動能力調査

Abstract: 【Objective】 This study examined the validity of measuring pre-school children's ability to stand on one leg with eyes open based on the correlation of its measurement with the survey results of preschool children's motor ability. 【Subjects】 The subjects were 173 preschool children aged 4-6 years old, with an average age of $66.9 \pm 6.8$ months. (Methods】 We measured the duration of the subjects' ability to stand on one leg with eyes open, and then tested their motor abilities through 25-m sprint, standing long jump, throwing a ball, hopping on both legs, and duration of being able to support the body weight, in accordance with the survey criteria on preschool children's motor ability as specified by the Ministry of Education, Culture, Sports, Science and Technology (MEXT). We then examined the correlations with the time of being able to stand on one leg with eyes open and the results of motor ability tests using Pearson correlation coefficients. IResults】We observed marked correlations between the time of being able to stand on one leg with eyes open and the motor test results for the 25-m sprint, standing long jump, hopping on both legs, and duration of being able to support the body weight. 【Conclusion】 Preschool children's ability to stand on one leg with eyes open is correlated with many motor abilities, suggesting the validity of its measurement.
\end{abstract}

Key words: preschool children, standing on one leg with eyes open, survey of preschool children's motor ability

\footnotetext{
受付日：2014年 5 月13日，採択日：2014年 6 月12日

1) 西九州大学リハビリテーション学部

干842-8585 佐賀県神埼市神埼町尾崎4490- 9

TEL : 0952-52-4191 E-mail : kuboa@nisikyu-u.ac.jp

Faculty of Rehabilitation Science, Nishikyushu University4490-9 Ozaki, Kanzaki, Saga, 842-8585, Japan. TEL +81952-52-4191

2) 京都橘大学健康科学部

Faculty of Health Science, Kyoto Tachibana University

3) 鎌倉リハビリテーション聖テレジア病院

Kamakura Rehabilitation St. Therese Hospital
} 


\section{I 、はじめに}

文部科学省は、幼児期における体力・運動能力の情 報について、それに関わる人が共有できるよう、「幼 児期運動指針」を発表した1”。この運動指針が示され た背景には、児童の体力・運動能力が1980年以降、長 期間にわたり低下している問題がある2)。览童の体力・ 運動能力の低下要因については、子どもの安全な遊び 場の減少や少子化による遊び友達の減少、習いごとに よる遊び時間の減少など、子どもを取り巻く環境の変 化や生活・社会的要因など多くの要因が指摘されてい る3,4)。また、览童の体力・運動能力を向上させるため には、幼児期の体力・運動能力を知り運動への理解を 深める必要がある。幼児期は、生涯にわたる運動全般 の基本的な動きを身につけ、身体機能、認知機能を発 達させる重要な時期である ${ }^{5)}$ 。しかし、これまで幼児 の体力・運動能力は、文部科学省より新体力テストに 基づく全国調査結果が公表される児童とは異なり公表 されていない。幼児期運動指針が示されたことにより、 今後は継続的な幼児の体力・運動能力を把握し、幼児 期の運動の意義についてあらゆる面から客観的に検討 し情報を共有することが必要となる。

幼児運動能力調査は、 $25 \mathrm{~m}$ 走、立ち幅跳び、ボール 投げ、両足跳び越し、体支持時間、補球の 6 項目から 成る6)。ただし、幼児の調査項目には、静的バランス 能力を評価する項目が含まれていない。運動能力が高 い子どもは立位姿勢保持能力の発達が顕著との報告や、 不良姿勢を取る児童はバランス能力が低下しているな ど、児童期以降のバランス能力については多くの報告 がある7.8)。しかし、幼児期に㧍けるバランス能力の研 究は少なく、矢部が行った立位姿勢と運動の発達との 関連を示した報告程度である ${ }^{9)}$ 。また、近年、保育現 場では転び方が下手で怪我をしやすい幼児が増えてい るという声が聞かれる ${ }^{10)}$ 。幼児の立位姿勢制御と運動 発達の基礎資料を得るためにも幼児のバランス能力の 特徵を明らかにすることは重要である。

本研究では、幼児の静的バランス能力の評価方法の 中より開眼片足立ちを選択した。従来、静的バランス 能力評価として重心動摇計による両足支持でのバラン ス評価が行われてきた ${ }^{11}$ 。しかし、保育施設内で多数 の幼児を対象とする体力測定の場では、機器を用いな い開眼片足立ちは導入しやすく、測定值について保護 者へのフィードバックも容易である。そこで、幼児の バランス能力研究の基礎研究として、開眼片足立ちと 他の運動能力測定項目值との関連性から、幼児に打け
る開眼片足立ち測定の妥当性を検討した。

\section{II. 対象と方法}

\section{1 . 対 象}

対象は、A市の幼稚園・保育園に通う、健常年中児· 年長児173名とした。平均月齢66.9 06.8 力月で、身長 は110.1 1 5. 3cm、体重は17.2 2 2. $4 \mathrm{~kg}$ であった。対象 児の保護者には、研究の趣旨と内容、得られたデー夕 は研究目的以外には使用しないこと、および個人情報 の取扱いには注意することに加えて、研究への参加は 自由であり参加しなくても不利益にはならないことを 文書にて説明し、その同意を得て研究を開始した。

\section{2. 方 法}

バランス能力評価として開眼片足立ち時間を計測し た後、文部科学省の示した幼览運動能力調査より $25 \mathrm{~m}$ 走、立ち幅跳び、ソフトボール投げ、両足跳び越し、 体支持時間を評価した6)。すべての項目は測定前に測 定方法を示範し、運動に失敗した場合はやり直した。

開眼片足立ちの測定は、文部科学省高齢者用新体力 テストに従い、開眼片足立ち位で姿勢保持できる時間 の上限を 120 秒として、デジタルストップウォッチを 使用して左右 2 回ずつ行い、その最長時間（秒）を代 表值とした ${ }^{12)}$ 。この際、対象者には裸足になること、 両上肢は体側につけておくこと、 $2 \mathrm{~m}$ 前方の視線と同 じ高さのマーカーを注視することを指示した（図 1)。

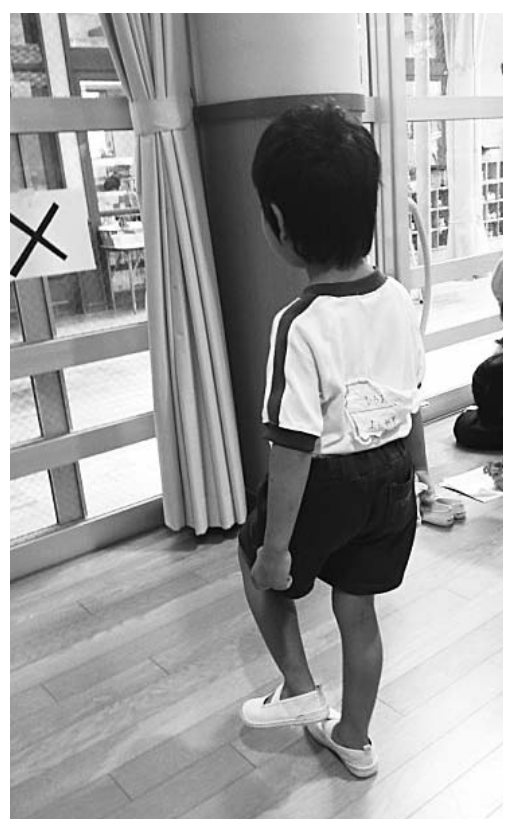

図 1 開眼片足立ち 


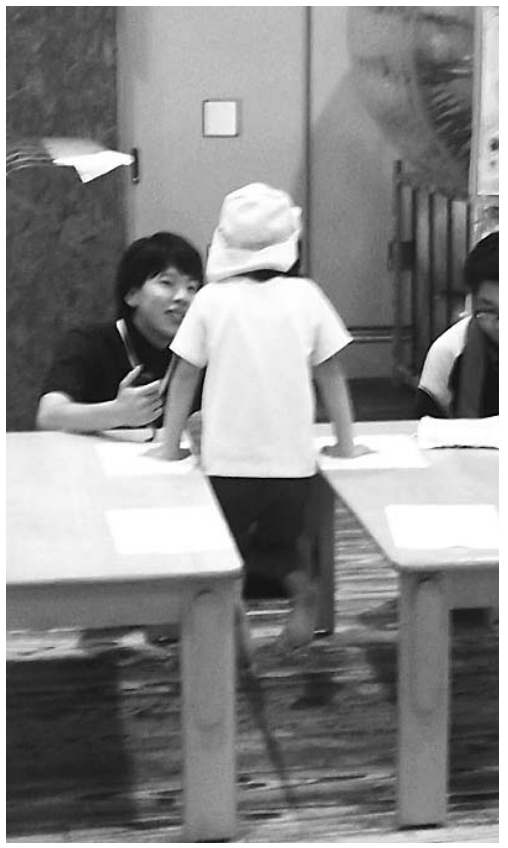

図 2 体支持時間

$25 \mathrm{~m}$ 走は、幼児運動能力調查実施要項に従い、屋外 で実施した6)。方法はスタートの合図で、直線距離を 走らせた。測定は 1 回実施しスタートの合図からゴー ルライン上に胴が到達するまで要した時間（秒）をデ ジタルストップウォッチにて計測した。

立ち幅跳びは、幼児運動能力調查実施要項に従い、 屋内で実施した。両足を軽く開き、つま先を踏み切り 線の前端に揃えるように立たせ、両足で同時に踏み切 り前方へ跳ばせた6)。記録は身体が床についた位置の うち、最も踏み切り線に近い位置と、踏み切り前の両 足の中央の位置とを結ぶ直線の距離（cm）を計測した。 2 回実施し、その最長距離を記録した。

ボール投げは、幼坚運動能力調査実施要項に従い、 ソフトボール教育 1 号を用いて屋外にて測定した6)。 方法は、投球ラインからボールを上手に投げてもらい、 ボールが落下した地点までの距離（m）を計測した。 記録は 2 回実施し、その最長距離を記録した。

両足跳び越しは、幼坚運動能力調査実施要項に従い、 スポンジ製の障害物 $(5 \mathrm{~cm} \times 5 \mathrm{~cm} \times 10 \mathrm{~cm})$ を $4.5 \mathrm{~m}$ の 距離に $50 \mathrm{~cm}$ の間隔で10個設置し、デジタルストップ ウォッチにて、スタートから10個跳び終わるまでの時
間（秒）を計測した6)。測定は 2 回行い、最短時間を 記録した。

体支持時間は、幼児運動能力調査実施要項に従い、 高さ70-75cmの机を対象児の左右に設置し、左右の台 に手をつき、合図とともに足を床から離し、両手で身 体を支持させ、再び足が床につくまでの時間（秒）を 計測した ${ }^{6)}$ (図 2 )。

統計処理は、開眼片足立ち時間と各評価項目值の関 係について、ピアソンの相関係数を用いて検討した。 なお、統計処理はSPSS17.0 J for windows を用い、統 計的有意水準は $5 \%$ とした。

\section{III. 結 果}

表 1 に対象者の月齢、身長、体重と各測定項目の平 均值ならびに 5 歳後半 (月齢66-71力月) 児の平均的 な值範囲を示す ${ }^{6}$ 。表 2 に開眼片足起立時間と各評価 項目值との相関分析の結果を示す。開眼片足立ち時間 は25m走、立ち幅跳び、両足跳び越し、体支持時間と の間の相関係数に有意性が認められた。25m走は非常 に弱い相関関係であり、立ち幅跳びと両足跳び越しは 弱い相関関係を示した。また体支持時間は中等度の相 関関係であった。ただし、ボール投げとは有意な相関 は認められなかった。

表 1 対象の属性と運動能力測定值

\begin{tabular}{lcl}
\hline \multicolumn{1}{c}{ 項 目 } & 測定值 & 基準值 \\
\hline 年齢 $($ カ) & $66.9 \pm 6.8$ & \\
身長 $(\mathrm{cm})$ & $110.1 \pm 5.3$ & \\
体重 $(\mathrm{kg})$ & $17.2 \pm 2.4$ & \\
開眼片足立ち(秒) & $39.4 \pm 32.5$ & \\
$25 \mathrm{~m}$ 走(秒) & $6.7 \pm 0.8$ & $6.2-6.9$ \\
立ち幅跳び $(\mathrm{cm})$ & $92.8 \pm 22.8$ & $89-114$ \\
ボール投げ(m) & $4.6 \pm 2$ & $3.5-7.0$ \\
両足跳び越し(秒) & $5.9 \pm 1.5$ & $5.0-5.9$ \\
体支持時間(秒) & $25.9 \pm 22.5$ & $25-53$ \\
平均值士標潐偏差 & & \\
N=173 & & \\
※基準值には 5 歳後半 (月齢66-71カ月) 児の平 \\
均的な值範囲を示す
\end{tabular}

表 2 開眼片足立ち時間と各測定值との相関分析

\begin{tabular}{|c|c|c|c|c|c|c|c|c|}
\hline & 年齢 & 身長 & 体重 & $25 \mathrm{~m}$ 走 & 立ち幅跳び & 両足跳び越し & 体支持時間 & ボール投げ \\
\hline 開眼片足立ち & $0.45^{* *}$ & $0.23^{* *}$ & $0.19^{*}$ & $-0.17^{* *}$ & $0.29^{* *}$ & $-0.23^{* *}$ & $0.48^{* *}$ & 0.13 \\
\hline
\end{tabular}




\section{IV. 考 察}

本研究は、幼児において開眼片足立ちを運動能力調 查として使用する意義について検討した。開眼片足立 ち時間はソフトボール投げ以外のすべての運動能力テ スト項目と有意な相関が認められた。開眼片足立ちと 有意な相関が認められた項目のうち、立ち幅跳びと 25 $\mathrm{m}$ 走は、全身の協応性や下肢筋力など総合的な運動能 力が関与する ${ }^{13)}$ 。開眼片足立ちと下肢筋力や身体機能 全般との関連については、成人ならびに高齢者で多く の報告があり ${ }^{14,15)}$ 、開眼片足立ちが幼児においても総 合的な運動能力を反映することを示唆するものである。 また両足跳び越しは、児童で測定が推奨されている反 復横とびと同様、敏捷性の指標とされる。敏捷性は、 神経系の円滑な連絡とその伝達速度および筋の収縮速 度によって形成され、幼児の姿勢制御は神経機能発達 と関連があることも報告されている ${ }^{11)} 。$

また、体支持は体を上方に引き上げる上肢筋力を必 要とし、幼児に理解しやすく最大筋持久力を評価する 測定項目とされる ${ }^{12)}$ 。高齢者において、握力は開眼片 足立ち以外にも立位バランス、下肢筋力など全身的な 体力を反映することが示されている ${ }^{16)}$ 。体支持時間も 特に上肢筋力を使う測定項目であり、相関が認められ たことは妥当な結果である。

一方、開眼片足立ちと有意な相関が認められなかっ たボール投げは、児童において出来る子と出来ない子 の差が広がっている運動能力の 1 つである。走る、跳 ぶといった日常的な単純動作と比較して、「投げる」 動作は、経験の差や本人の意欲の差に影響される ${ }^{17)} 。$ 特に幼児においては、ボールの飛距離ではなく動作の 洗練度を質的に評価する方法が試行されており ${ }^{18}$ 、開 眼片足立ちと関連しなかった点については動作パター ンの質的評価を含めて検討が必要である。

文部科学省は、昭和60年代から続く就学期以降の子 どもたちの体力低下を抑制するため、平成23年度、そ の前段階の $3-6$ 歳児に注目し、「幼児期の運動指針」 策定を検討した ${ }^{1}$ 。今後、幼児期における運動の必要 性への関心が高まることが期待される。本研究の結果、 バランス能力評価の 1 つである開眼片足立ちは、幼児 にも理解しやすく、特別な装置も必要なく簡便であっ た。また、本研究の対象者とした年中ならびに年長児 では測定中に転倒する幼児もおらず安全に実施できた。 開眼片足立ち時間と他の運動機能との関連が認められ たことから、幼児においても開眼片足立ちは、多くの 運動機能を反映する評価であり、幼览期における開眼
片足立ち測定の妥当性が示唆された。

ただし、開眼片足立ちと相関係数に有意性が認めら れた項目のうち、25m走では非常に弱い相関、立ち幅 跳びならびに両足跳び越しについては弱い相関に止 まった。デンバー式発達スクリーニング検査において 開眼片足立ちの $90 \%$ 通過率は 4 歳児で 2 秒、6 歳児で は20秒前後可能となる ${ }^{19}$ 。 $25 \mathrm{~m}$ 走においては、4 歳児 と 6 歳児で基準值に 2 秒の違いがある ${ }^{6)}$ 。このように 幼児期は、短期間で運動能力が著しく向上する時期で ある。また、重心動摇検査において 4 - 5 歳児では男 児と比較して女児の動摇が少ないことが報告されてい る ${ }^{20)}$ 。本研究の限界として、対象を年中・年長児（月 齢幅24力月）としたが、各運動能力測定值と月齢の影 響については、調整していない。今後の課題として、 幼児の開眼片足立ち時間の数值の持つ意義を明らかに するためには、対象児数を増やし、月齢別ならびに男 女別の検討を行うことが必要である。

\section{引用文献}

1) 文部科学省：幼児期運動指針.

http:/ / www. mext.go.jp / a_menu / sports / undousisin / 1319771.htm （閲覧日2014年 4 月15日）

2 ）日本レクレーション協会：子どもの体力向上 http://www.recreation.or.jp/kodomo/image/top_01.jpg （閲覽日2014年 4 月15日）

3 ）高橋亮輔，岡田真平，渡邊真也・他：小学生の身体特性㧍 よび生活習慣について. 身体教育医学研究, 2006, 7 (1) 25-30.

4 ）新本惣一郎, 山崎昌廣：小学生の体力と身体活動量の関係. 発育発達研究, 2013，61：9-18.

5 ）中路純子：リハビリテーションのための人間発達学. 大城 昌平編，メディカルプレス，東京，2012，47-53.

6）文部科学省：体力向上の基礎を培うための幼児期における 実践活動の在り方に関する調查研究幼巟運動能力調查. http://www.mext.go.jp/a_menu/sports/youjiki/index.htm （閲覧日2013年 5 月 7 日）

7 ）盛田知広, 鎌田安久, 清水茂幸・他：児童の静的及び動的 バランス能力の評価。岩手大学教育学部附属教育実践総合 センター研究紀要, 2012, 11: 71-77.

8 ）津山薰, 大和眞, 榎本静香 ·他：小学生の重心動摇に関す る研究一総軌跡長・外周面積を指標として一。 日本体育大 学紀要, 2004, 34(1)：37-45.

9 ）矢部京之助：姿勢と発達。体育の科学，1994，44：31-36.

10）曽根章友，村上智子：ベテラン保育士が捉える子どもの育 ちの変化(1) 3 歳以上児の場合. 山形短期大学紀要, 2009, $41: 77-99$

11）新宅幸憲：幼児期の立位姿勢における静的平衡性について。 彦根論叢, 2012, 391：18-49.

12）文部科学省：新体力テスト. 
http://www.mext.go.jp/a_menu/sports/stamina/03040901.

htm

（閲覧日2013年 5 月 7 日）

13）春日晃章：幼児のからだを測る - 知る. 村瀬智彦, 春日晃 章, 酒井俊郎編, 杏林書院, 東京, 2011, 40-63.

14）宮崎純弥, 村田伸, 堀江淳 - 他：男性高齢者における30秒 間の開眼片足立ち保持ができる意義. 理学療法科学, 2010, $25(3): 379-383$.

15）村田伸, 甲斐義浩, 溝田勝彦 - 他 : 地域在住高齢者の開眼 片足立ち保持時間と身体機能との関連. 理学療法科学, 2006, 21 (4) : 437-440.

16）池田望, 村田伸, 大田尾浩 - 他：地域在住女性高齢者の握 力と身体機能との関係. 理学療法科学, 2011, 26(2) : 255 -258 .

17）春日晃章 : 幼児期における体力差の縦断的推移：3 年間の 追跡デー夕に基づいて。発育発達研究，2009，41：17-27.

18）佐々木玲子, 中村和彦：幼児期運動指針実践ガイド。日本 発育発達学会編, 杏林書院, 東京, 2014, 106-109.

19）W.K.Frankenburg,MD：デンバー発達判定法. 日本小児保 健協会編，日本小児医事出版社，東京，2005，28.

20）中林俊克 : 児童の平衡機能の発達について-重心動摇検査 を通して一. 神戸大学発達科学部研究紀要, 1997, 4(2)： 1 - 21 . 